\title{
Vertical Specialisation and Regional Trade Integration. A Study on Italy and Northern African Countries
}

\author{
Giancarlo Corò, Marco Giansoldati, Mario Volpe \\ Ca' Foscari University of Venice
}

First Draft: December 2010

\begin{abstract}
This paper uses a multistage approach to investigate the role of Italy in the Northern African countries, both in terms of trade and investment.

In particular, we show that Italian import flows for two typically Made in Italy industries, namely textile and clothing on one hand, and leather and footwear on the other hand, are strongly related not only to export flows of the same sector, but also to a set of variables capturing features of the Italian and the foreign country. In this way, we supply a first result supporting the hypothesis of an international fragmentation of production. To offer this outcome additional strength, we endow the present contribution with information on the attractiveness of the Northern African countries, looking at the volume of inward FDI flows and stocks, but with no industry disaggregation, due to data unavailability. Although we start from a global perspective, we rapidly shift to consider only the Italian investments in the area, with a breakdown by outward region. Thanks to the availability of a detailed dataset made available by the Bank of Italy, we are able to provide further evidence on the Italian internationalisation in the North of Africa. Indeed, our second result highlights the remarkable heterogeneity across countries and the emergence of the major role played by Tunisia.
\end{abstract}

\section{Keywords}

Northern Africa, Italian regions, Made in Italy, FDI, fragmentation, Global Value Chains

\section{JEL Codes}

F14, F21, F23, L67

\author{
Address for correspondence: \\ Marco Giansoldati \\ Department of Economics \\ Ca' Foscari University of Venice \\ Cannaregio 873, Fondamenta S. Giobbe \\ 30121 Venezia - Italy \\ e-mail: marco.giansoldati@unive.it
}

This Working Paper is published under the auspices of the Department of Economics of the Ca' Foscari University of Venice. Opinions expressed herein are those of the authors and not those of the Department. The Working Paper series is designed to divulge preliminary or incomplete work, circulated to favour discussion and comments. Citation of this paper should consider its provisional character.

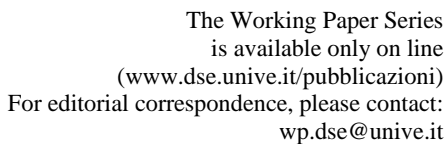

Department of Economics

Ca' Foscari University of Venice

Cannaregio 873, Fondamenta San Giobbe

30121 Venice Italy

Fax: ++39 0412349210 


\section{Introduction}

Anedoctical evidence suggests that trade and productive integration between Italy and Northern African countries have become increasingly tighter during the last two decade or so.

This paper not only provides detailed data on trade flows between selected Italian regions and Northern African countries, but it also supplies information on the evolution of Italian FDI towards that area. Using a detailed data set on trade flows at Italian regional level, we demonstrate that there is a strong linkage between imports and exports within two different industries, namely textile and clothing on one hand, and leather and footwear on the other hand. Moreover, we also noticed that domestic imports for these two sectors show relevant and coherent relationships with both a number of Italian and foreign variables. Particular attention is paid to regional heterogeneity, in terms of trade partners and volumes, as well as in terms of trade elasticity to variations in productivity. We are able to supply not only some descriptive statistics on the volume of FDI net flows from selected Italian Regions to the Northern African countries, but also to compare (although with some limitations due to data availability) the role of our country vis-à-vis that of other relevant partners active in the Region.

Results push to reconsider some of the Northern African countries not only as mere source of localised comparative advantages but mainly as a strategic place where the bulk of Italian district firms manufacture the so-called Made in Italy goods.

\section{Vertical Specialisation: Some Definitions}

An element that seems to have played an important role in export performance over the past decade is the extent to which countries have participated in vertical supply integration processes. According to the findings of Miroudot and Ragoussis (2009 [4]), there seems to be a positive relationship between export performance and the share of vertical trade in each country's total trade. This may be useful to understand the role played by FDI in Eastern European countries as well as the substitution of locally-produced inputs by imported ones in Germany, similarly to what has taken place in Italy in the recent past. It can also partly explain the weaker export performance of countries such as France or Japan which have used a different strategy of exporting from third countries or producing locally, namely by using an export-plarform FDI strategy.

Indeed, contrary to export-platform, 'vertical specialisation' is solely associated with vertical FDI, that is investment seeking to exploit cross-country productivity differentials. The term becomes relevant when firms exploit efficiency advantages at multiple stages of the value chain by linking sequentially facilities located in several countries. To be more precise, 'vertically specialised' production is the one using foreign inputs, but whose output is not to be used or consumed in the destination market.

We can easily notice the difference between vertical specialisation, and simple trade in intermediate goods: in the former case there is trade in intermediate goods bringing inputs inside the country but also trade in intermediate or final goods taking the outcome beyond the borders. The central element in defining 'vertical specialisation' is the fact that the outcome does not remain within the borders of the local market, but there are back-and-forth transactions (Ando, 2006 [1]) which may give rise either to vertical intra-industry trade or one-way trade. Kimura and Ando (2005 [3]) proposed a measure of two-dimensional fragmentation based on geographical distance and on uncontrollability. The former measure states that differences in location advantages are exploited when the service link costs due to the geographical fragmented production block is overcome, whereas the latter recalls the problems arising when fragmentation goes beyond the boundaries of the firm, such as weaker managerial control. In this case, the increase in service link costs derives from uncontrollability, whereas "the reduction of production costs is generated by de-internalisation advantages or the counterparts' ownership advantages" (Kimura 
and Ando, 2005 [3], p. 318).

The dimension of vertical specialisation not only depends on a country size, but also on its geography. Countries located nearby (such as in Central Europe and Northern Africa) are more likely to receive FDI for vertical specialisation as the exploitation of national comparative advantages at each production blocks comes at significantly lower transportation costs if compared to isolated nations.

\section{From Vertical Specialisation to Value Chains: Some Sketchy Facts on the Propagation of Italian Firms in Northern Africa}

This Section aims at providing some preliminary results on the geographic orientation of Italian trading partners in manufactures. Namely, we are interested in showing that a process of deep integration has been taking place so far between most Italian regions and some countries located in the North of Africa. Such a phenomenon shows a significant path of co-dependence between import and export flows, especially in textile, wearing and apparel, on one hand, and leather and footwear, on the other, although within broad industry classifications (the ATECO 2 digit level). As far as the first group is concerned, we notice that there has been a growing amount of raw textiles shipped overseas from some Italian regions to Tunisia and Egypt in order to be further processed at a lower cost than domestically. If looking, instead, at import composition but at a narrower level, we noticed that Italian regions often import finished product to be either placed on the internal or on the external market. This is almost the same phenomenon which takes place within the leather and footwear industry, although such a fact is far more difficult to be isolated due to data availability. However, we may hypothesise that parts and components made of leather are produced in Italy, then exported abroad just to be further processed and finally re-imported.

What seems more striking is that the complex trade integration in consumer goods between Italian regions and the selected countries brings about a significant rise in the domestic export of machinery and equipment needed to perform technical transformation abroad. In other words, there is evidence supporting the view that fragmentation not only matters for low-tech goods, but also for related capital goods which are exported abroad to allow for operations to cope with buyers' specifications.

\subsection{The Model: Empirical Specification}

We will provide here our estimates for a panel made up of Italian regions, limited to the 'textile and clothing' and 'leather and footwear' industry, to study the evolution of import flows from some Northern African countries (Tunisia, Egypt, Morocco and Algeria ${ }^{1}$ ). In order to perform our analysis we used a two-way static panel data approach with the following structure:

$$
y_{i, t}=X_{i, t} \beta+\mu_{i, t}
$$

where $y_{i, t}$ is the dependent variable (the level of import of a given region), $X_{i, t}$ is the $n \times K$ matrix of explanatory variables and $\beta$ is a $K \times 1$ vector of parameters. It is assumed that $\mu_{i, t}$ follows a two - way error component model:

$$
\mu_{i, t}=\mu_{i}+\lambda_{t}+v_{i, t}
$$

where $v_{i, t} \sim \operatorname{IID}\left(0, \sigma_{v}^{2}\right)$.

\footnotetext{
${ }^{1}$ From the estimates concerning both the textile and clothing industry and the leather and footwear sector, we drop the case of Algeria as trade flows with the Italian regions were not statistically significant in the descriptive statistics we already provided.
} 
In particular $\mu_{i}$ denotes the regional-specific residual differing across partner countries, while $\lambda_{t}$ the year-period effect. Indeed the levels of trade are very different among regions and also have different magnitudes for each partner country considered. Under these circumstances the estimated standard errors of the parameters and the variance-covariance matrix estimates are inconsistent for the presence of both heteroschedasticity and serial correlation. In order to account for these econometric issues we used the Newey-West (1987) covariance matrix estimator, consistent in the presence of both heteroskedasticity and autocorrelation, and a feasible Generalised Least Square (GLS) specification for our model.

The explanatory variables used in the analysis are the following:

- EXPORT represent regional exports towards the selected countries. The coefficient is positive and significant. This variable measures imports' elasticity on exports, i.e. how imports change if exports show a certain percentage variation, first for the textile and clothing industry and then for the leather and footwear sector.

- LNPRODGROW represents the ratio between the industry and services productivity logaritmic growth rate.

- LNAVFOREIGN is the logarithm of the added value (expressed at current prices, base year 2000) of the foreign partner country. The coefficient is positive and statistically significant. The elasticity is less than one.

- XRFOREIGN is the logarithm of the bilateral real exchange rate. This variable carries a positive sign and its elasticity is less than one.

- DISTANCE is the logarithm of the kilometric distance between the regional capital city and the partner country capital city. Obviously, this variable is a proxy of transportation costs.

- DPARTNER is a country dummy.

- DREGION is a regional dummy.

- DYEAR is a yearly dummy.

All variables are expressed in logarithms in order to interpret the coeffcient as the responce elasticity of the dependant variable to a percentage variation of the explanatory variables.

We divided the original sample of twenty Italian regions in two subsamples. The first, denoted as 'TypeA Regions', indicates those regions with higher trade flows, while the second, denoted as 'TypeB Regions', those with lower trade volumes, finally the whole sample was labelled as 'Type A+B Regions'. Such a distinction is primarily oriented to understand if the Regions which are the most involved in the imports of goods, are, at the same time, those showing higher export flows towards the selected partner countries. As a logic consequence we also expect 'TypeA Regions' import flows to be more sensitive to changes in the variables regarding macroeconomic condition of the counterpart.

Firstly, we focus on the textile and clothing industry.

If looking at Table 1 we noticed that the elasticity of imports' due to a variation in exports is very different if looking at 'TypeA Regions' rather than to 'TypeB Regions'. In both cases

\footnotetext{
${ }^{2}$ 'TypeA Regions' are Piedmont, Lombardy, Veneto, Emilia-Romagna, Tuscany, Lazio, Marche, Abruzzo, Apulia and Campania.

'TypeB Regions' are all other regions.
} 
the coefficient is statistically significant, but it is more than double in the former group. If considering the whole sample the coefficient is signficant and its value is fairly close to the one expressed by 'TypeB Regions'.

'TypeA Regions' show a significant and positive sign for the variable that measures the variation in productivity, conversely to what takes place for the group of 'TypeB Regions', where the variable is not significative and carries a negative sign. If looking instead at the whole group of regions the variation on productivity carries again a positive and signficant sign, whose value is strangely higher than the sole 'TypeA Regions'.

Similarly, the coefficient expressing the added value of the foreign partner country is positive and significant for 'TypeA Regions', while it's close to zero for 'TypeB Regions'. If looking, again, at the whole sample the coefficient is again positive and largely significant. By considering these sketchy results we may suppose that trade relations with the Mediterranean area mostly depend on the ability of a partner country to supply competitive services for the manufacturing of raw materials (supposing the existence of an intra-industry relation). Indeed, a percentage variation in the added value of the foreign country is able to produce a proportional increase in the import flows fro thart areas. This phenomenon signals the presence of trade flows which are more likely to create commercial linkages with countries focusing on high value added functions (Gereffi, Humphrey and Sturgeon, 2005 [2]).

- Table 1 about here -

Secondly, we focus on the leather and footwear industry.

There are striking differences between the results showed for the 'TypeA Regions', TypeB Regions' and, especially, the whole sample.

The elasticity of imports to exports is significant all along the three sample, but the coefficient is higher for the 'TypeA Regions', actually four times higher circa than what takes place for the complete dataset, and ten times higher than the coefficient expressed for 'TypeB Regions'.

Contrary to the textile and clothing industry, the coefficient for the variation of the productivity is not significant in this sector if the two regional samples are considered independently, but it becomes significat if looking at the entire one.

As far as the added value of the foreign country we find an expected positive sign, which is largest for 'TypeA Regions', and almost the double of the coefficient of the 'TypeA Regions' and of the overall sample. Different results emerge, instead, if considering the exchange rate and distance. In the former case, the value is negative and the coefficient is signficant just only for 'TypeA Regions' and for the total sample. In the latter case, the coefficient is negative (as expected), and largely signficant only for the case of 'TypeA Regions'.

- Table 2 about here -

\section{FDI in Northern Africa: From the European Dimension to the the Italian Regional Level}

The second part of our paper aims at providing some detailed data on the both flows and stocks of inward FDI that involved some Northern African countries from 1996 to $2007^{4}$. In the first place we will only focus on inward FDI disregarding where capital comes from; then we shall move more in detail by considering the role of some EU contries (thanks to UNCTAD data) and to a deeper level by focusing on the role of Italy and of each region, compatibly with

\footnotetext{
${ }^{4}$ Sometimes the time span will be shorter, for example from 1996 to 2006 or from 1997 to 2007 due to the lack of data for the selected partner country.
} 
available data sources (again UNCTAD and Ufficio Italiano Cambi - Bank of Italy). We wish to put particular emphasis on a comparison between different Northern African countries to understand their role not only in the Northern Africa region but also within the whole African continent.

\subsection{Northern African Countries: a Continental Comparison}

The analysis we undertook on FDI starts by comparing inward and outward flows among Morocco, Algeria, Tunisia Egypt, but also with the total Northern Africa area ${ }^{5}$ and the entire African continent.

Flows are, for their nature, extremely volatile and this implies a complicated interpretation. Nevertheless it is possible to briefly compare the data, especially for the most recent years. We are thus able to note that Egypt is the most attractive among the selected countries, with more than 11 billion Dollar of inward FDI. This is almost half of all flows directed to Northern Africa and approximately one fifth of the capital directed to the whole continent.

- Table 3 about here -

Once provided the above descriptive data on inward FDI flows, we supply some additional information by computing the incidence of such flows on the gross capital formation. Clearly these data follow the erratic path shown by the flows themselves, but, nevertheless, we are able to formulate some limited reflections. In particular, we notice that the digit for Algeria has never been higher than 10\% so far, which is a similar level expressed by Egypt till the year 2003 . A certain stationarity is expressed by Tunisia, whose percentage remains for most of the time under the $20 \%$ threshold. Eventually, Morocco shows a higher variability than the other cited countries with a peak in the year 2001 followed by declining values in the years after.

- Table 4 about here -

- Figure 1 about here -

Let us now look at the stock of FDI accumulated by each country, analysing them by a decreasing order of inward capital volumes. The remarkable value of FDI inward flows received by Egypt contributed to the built up of a notable stock of FDI, which is greater than that of the other selected countries since 1996. The digit showed an increase of more than 35 billion Dollars, soaring from 15 billions to 50 billions at the end of 2007, almost one third of all FDI stocks directed to Northern African countries and approximately $12.5 \%$ of the total stocks invested in the continent. Following Egypt we find Morocco, which shows a lower value of FDI stocks than Tunisia in the year 1996, but the digit then rises and overcomes Tunisia in 2003, experiencing later a steep increase from 2004 to 2007, reaching more than 30 billion Dollars. We then isolate Tunisia whose inward FDI stock is constant till the year 2001, then slowly rises till 2004 and shows a remarkable progress from the year 2005. Eventually, we find Algeria that shows an increase in its FDI stock but the registered value is always very low. This is presumably due, for a signficant extent, to the political instability and the high terroristic risk that affect the country.

- Table 5 about here -

- Figure 2 about here -

\footnotetext{
${ }^{5}$ Plaese note that according to the UNCTAD nomenclature, the geopolitical area called 'Northern Africa' also includes Western Sahara, Sudan and Lybia.
} 
Significant values can be obtained if looking at what is the incidence of FDI stocks on a country GDP.

- Table 6 about here -

- Figure 3 about here -

From 1996 onwards Tunisia is the country where the stock of inward FDI presented the highest incidence on GDP, soaring from values slightly lower than $60 \%$ to more than $75 \%$ at the end of 2007. These data are far higher than those expressed not only by all other selected countries but also by all macroeconomic aggregates we considered. Amongst other states we recorded a significant increase for the value attributable to Morocco, rising from $13 \%$ to $44 \%$, but also for the digit concerning Egypt which showed a increase of almost twenty percentage points, from $19 \%$ to $38 \%$.

The states we studied, show at the end of 2007 a ratio between inward FDI and GDP which is higher than the value expressed by North Africa as a whole and by the entire African continent. These latter aggregates do not show such a differen path, as they both start from a percentage of $15 \%$ and reach $30 \%$ at the end of 2007 with no particular erratic movements along the time span.

Algeria shows a low stock of inward IDE, not only in absolute terms but also in terms of GDP. Digits show an increase from $4 \%$ circa to 10\%, remaining stationary till the year 2007 .

\subsection{The Italian Firms in the Northern African Countries}

Thanks to the data provided by the ICE-Reprint database - Milan Politecnic, we are able to supply some descriptive indications on the role played by Italian firms in Morocco, Tunisia, Algeria and Egypt. In particular we will consider

- the number of foreign firms participated by Italian firms;

- the number of foreign firms' employees participated by Italian firms;

- the turnover of foreign firms participated by Italian firms and

- the turnover per employee of foreign firms participated by Italian firms.

Such information are provided for the country of interest and compared with both some European countries (with whom Italy has a strong economic linkage) and with the so-called BRIC countries (Brazil, Russia, India and China).

The Italian presence in Northern African countries has slightly increased from the beginning of 2002 to the beginning of 2008, soaring from 528 to 618 units. Such a dynamic is a common feature of all the selected nations, although there is surely a certain degree of heterogeneity amonst them in terms of 'weight'. By looking at Table 6 we notice that the Italian presence is highest in Tunisia, with almost 300 units at the beginning of the year 2008, which is approximately half of all Italian firms operating in North Africa.

The number of foreign firms participated by Italian companies in the three remaining countries is quite the same, although Morocco preceeds Egypt and eventually Algeria.

- Table 7 about here -

- Figure 4 about here - 
By looking at Table 7 and Figure 6 we are able to retrieve some remarkable information on the evolution of the number of employees working for foreign firms participated by Italian companies.

The four countries all together showed an increase of about 7,000 employees, especially from the beginning of 2005 and 2006, reaching more than 42,000 units.

As far as each country is concerned, we notice immediately the small role played by Algeria, a country always showing a level lower than 2,000 units. Opposite, we notice the signficant position of Tunisia with more than 20,000 units at the beginning of 2008, registering a slight upsurge from the year 2002 .

It is also remarkable the number of employees working in Morocco, approximately 11,000, higher than the digit recorded by Egypt. In this case, there has been a very slow increase from 2002 to 2005 , followed by a jump of 4,000 units in the year 2006, thus leading to more than 8,000 employees at the beginning of 2008 .

- Table 8 about here -

- Figure 5 about here -

The turnover realised by foreign firms participated by Italian companies is, in the year 2008, higher not only than that recorded in China, but also than that registered in Russia and India as well. Such data does not mean that Italy has no economic linkages with the so-called BRICs, but it may emphasise that trade linkages do not go hand in hand with equity investment, contrary to what has taken place so far in the Northern African countries.

In this latter area the turnover more than doubled along the time span, with a value rising from 3,700 million Euros to 8,000 circa mostly due to the upsurge in the years 2005 and 2006.

In absolute terms Egypt showed the highest turnover value (more than 3,200 million Euros in 2008), followed by Algeria (2,000 millions), then by Tunisia (1,700 billions) and Morocco (1,000 billions circa).

All selected countries experienced an increase in turnover, although Algeria and Egypt showed the major rise, just between 2005 and 2006.

- Table 9 about here -

- Figure 6 about here -

An additional measure we dedided to analyse is the amount of turnover per employee. Such data grew for all the selected countries, rising from 105,000 Euros to almost 190,000, but it is the result of national heterogeneous patterns sometimes. Morocco and Tunisia present at the beginning of 2008 a very similar value, approximately 80,000 Euros, whilst different are the cases of Egypt and Algeria. In this latter case there has been a signficant rise between 2005 and 2006, and a slower growth afterwards, overcoming the 1,000,000 threshold. As far as Egypt is concerned the pattern is much more unstable, with periods of rapid rises followed by slowdowns.

- Table 10 about here -

- Figure 7 about here -

\subsection{The Italian Regions in the Northern African Countries}

The picture we are able to draw by looking at all tables allows us to note that outward flows form Italian regions to the selected Northern African countries are extremely low.

By looking, in more detail, to each of the nations, we noticed the limited relevance of Algeria 
whose attractivity is extremely low, especially for the political instability that affects the country. ${ }^{6}$

By comparing, instead, all the regions, to look for the highest and persistent FDI outward flows we are able to isolate the leading region, namely Lombardy, who has a strong linkage with Egypt, but it also expresses remarkable links with Tunisia and Morocco. The second place is occupied by Veneto with a significant outward flow towards Tunisia, which is the preferred destination also for capital coming from Piedmont (standing at the third place). In such two cases the presence of areas traditionally specialised in the textile and clothing industry seems to support our previous findings on trade linkages with Tunisia. This is indeed the most involved country in both imports and exports of intermediates and final products pertaining to a broad range of textile goods.

Emilia-Romagna follows in the fourth place, showing a special relation with Egypt.

Lower values are then expressed by the other regions. Nevertheless, it is worth citing Lazio with approximately 20 billion Euros directed mostly to Tunisia, then Marche with 17 millions circa and eventually Sicily an Abruzzo, with 14 and 10 millions respectively, most of them directed again toward Tunisia.

- Tables from 11 to 24 about here -

\subsubsection{The Italians in the Northern African Countries: Evidence from a Measure of Flow per Employee}

As official statistics do not always provide the stock of outward IDE from Italy to other countries, included those of our interest, we decided to proxy it with the number of Italian employees abroad and compute the volume of trade flow per employee. ${ }^{7}$

Elements supporting the consistency of our measures emerge from Table 25, where we can compare the data of the Northern African countries with those that are tightly link with Italy as well as with the so-called BRICs.

- Table 25 about here -

Data are mostly growing during time, with higher digits for Germany, France and Spain, countries where the Italian presence in terms of employees is able to generate higher trade volumes if compared to other nations. In other words, there is a greater leverage effect the greater is the reported value, justifying, in the case of Europe, the presence of persistent and solid economic linkages with Italy.

In this sense, there might be some reasonable doubt if looking at the Russian value for the year 2007, as it is higher than that of France and Spain. Such a result depends on the structural differences between partner countries, for some of them, such as Germany, there is a remarkable process of commercial and productive integration with Italy. Conversely, in the relationship between Italy and Russia we detect a relevant volume of Italian import of oil and gas but a comparatively low value of Italian outward FDI flows to Russia, and of employees as well.

Setting aside from these specifications, we are also able to define some peculiarities for the African countries we are interested in.

Within the North of Africa, Egypt shows the highest value, a country that already in the year 2001 showed a remarkable level. Much more lower are the digits presented by Tunisia and Morocco, with a steady rise all along the time span.

\footnotetext{
${ }^{6}$ Marche is an exception as we recorded a flow of FDI which is, however, not followed by further flows in the years after.

${ }^{7}$ Data are expressed in US Dollars at current prices.
} 
It is quite hard to provide a comparison between the Northern African countries and the socalled BRICs, that present an enourmous economic power and are extremely different one from the other.

\section{Conclusions}

The present paper provides a little but significant advancement in the study of Italian internationalisation. In particular, it first supplies econometric evidence on the internationalisation of two Made in Italy industries, namely textile and apparel on one hand, and leather and footwear on the other, towards a specific area, i.e. Northern Africa. The estimates of the gravity model generally support the idea of an international fragmented production system. Indeed, we noticed that there has been a growing amount of raw textiles shipped overseas from some Italian regions to Tunisia and Egypt in order to be further processed at a lower cost than domestically. If looking, instead, at import composition but at a narrower level, we noticed that Italian regions often import finished product to be either placed internally or abroad. This is almost the same phenomenon which takes place within the leather and footwear industry. More strikingly, the complex trade integration in consumer goods between Italian regions and the selected countries brings about a significant rise in the domestic export of machinery and equipment needed to perform technical transformation abroad. Secondly, the paper contributes to the analysis of FDI flows and stocks directed to the Northern African countries. Although such a part is mostly descriptive, we were able to isolate some significant facts concerning the linkages between Italy and its regions with selected partner countries. Sometimes regions which trade more with a country are also more inclined to invest. This is not always the case, and further research is needed to shed some light on this topic. 
Table 1: Estimates for the model on the textile and clothing industry

\begin{tabular}{|c|c|c|c|}
\hline & $\begin{array}{l}\text { TypeA Regions } \\
\text { Coefficient }\end{array}$ & $\begin{array}{l}\text { TypeB Regions } \\
\text { Coefficient }\end{array}$ & $\begin{array}{l}\text { TypeA+B Regions } \\
\text { Coefficient }\end{array}$ \\
\hline Constant & & $4.94^{* *}$ & \\
\hline EXPORT & $0.72^{* * *}$ & $0.31^{* * *}$ & $0.38^{* * *}$ \\
\hline LNPRODGROW & $0.6^{* * *}$ & -0.22 & $0.64^{* *}$ \\
\hline LNAVFOREIGN & $0.78^{* * *}$ & 0.04 & $0.63^{* * *}$ \\
\hline XRFOREIGN & -0.46 & -0.84 & $-0.37 * *$ \\
\hline DISTANCE & $-0.53^{* *}$ & & \\
\hline \multicolumn{4}{|c|}{ Country Effects } \\
\hline MOROCCO & $-4.06^{* * *}$ & $-3.48^{* * *}$ & $-4.4^{* * *}$ \\
\hline EGYPT & $-2.27^{* * *}$ & $-0.94 * * *$ & $-2.8^{* * *}$ \\
\hline TUNISIA & & & \\
\hline \multicolumn{4}{|c|}{ Regional Effects } \\
\hline PIEDMONT & $1.34^{* * *}$ & & $3.46^{* * *}$ \\
\hline LOMBARDY & $1.38^{* * *}$ & & $3.69 * * *$ \\
\hline VENETO & $1.9^{* * *}$ & & $4.18^{* * *}$ \\
\hline EMILIA-ROMAGNA & $0.99^{* * *}$ & & $2.85^{* * *}$ \\
\hline TUSCANY & $0.81^{* * *}$ & & $2.98^{* * *}$ \\
\hline ABRUZZO & $0.83^{* * *}$ & & $2.97^{* * *}$ \\
\hline MARCHE & -0.01 & & $1.86^{* * *}$ \\
\hline UMBRIA & & $1.62^{* * *}$ & $1.41^{* * *}$ \\
\hline AOSTA VALLEY & & 0.48 & 0.75 \\
\hline TRENTINO-ALTO ADIGE & & $-0.71^{*}$ & -0.47 \\
\hline LIGURIA & & $0.73^{*}$ & $0.49^{*}$ \\
\hline FRIULI-VENEZIA GIULIA & & 0.55 & -0.01 \\
\hline LAZIO & & & $1.61^{* * *}$ \\
\hline APULIA & & & $2.1^{* * *}$ \\
\hline CAMPANIA & & & $1.92^{* * *}$ \\
\hline CALABRIA & & $-0.77^{* * *}$ & $-0.77^{* *}$ \\
\hline SICILY & & $1.62^{* * *}$ & $1.21^{* * *}$ \\
\hline SARDINIA & & $0.94^{* *}$ & 0.66 \\
\hline \multicolumn{4}{|c|}{ Time Effects } \\
\hline DYEAR02 & $0.08^{*}$ & -0.03 & \\
\hline DYEAR03 & -0.07 & -0.21 & -0.07 \\
\hline DYEAR04 & $-0.2^{* *}$ & -0.2 & $-0.11^{* * *}$ \\
\hline DYEAR05 & 0 & $-0.45^{* *}$ & $-0.05^{*}$ \\
\hline DYEAR06 & -0.03 & $-0.41 * *$ & -0.06 \\
\hline DYEAR07 & -0.1 & -0.14 & \\
\hline$\overline{\mathrm{R} \text {-squared }}$ & 0.72 & 0.71 & 0.82 \\
\hline
\end{tabular}

Note: ${ }^{* * *},{ }^{* *}$ and $*$ indicate significance at $1 \%, 5 \%$ and $10 \%$ respectively. 
Table 2: Estimates for the model on the leather and footwear industry

\begin{tabular}{|c|c|c|c|}
\hline & $\begin{array}{l}\text { TypeA Regions } \\
\text { Coefficient }\end{array}$ & $\begin{array}{l}\text { TypeB Regions } \\
\text { Coefficient }\end{array}$ & $\begin{array}{l}\text { TypeA+B Regions } \\
\text { Coefficient }\end{array}$ \\
\hline \multicolumn{4}{|l|}{ Constant } \\
\hline EXPORT & $0.82^{* * *}$ & $0.09 * * *$ & $0.21 * * *$ \\
\hline LNPRODGROW & -0.41 & -0.09 & $-0.07 * * *$ \\
\hline LNAVFOREIGN & $1.20^{* *}$ & $0.52^{* * *}$ & $0.53^{* * *}$ \\
\hline DISTANCE & $-1.66^{* * *}$ & -0.01 & $-0.50 * * *$ \\
\hline XRFOREIGN & $-1.67 * * *$ & & \\
\hline \multicolumn{4}{|c|}{ Country Effects } \\
\hline MOROCCO & $-6.31 * * *$ & $-1.38 * * *$ & $-3.46^{* * *}$ \\
\hline EGYPT & $-4.01 * * *$ & $-1.88^{* * *}$ & $-2.49 * * *$ \\
\hline \multicolumn{4}{|c|}{ Regional Effects } \\
\hline PIEDMONT & $2.05^{* *}$ & & $2.66^{* * *}$ \\
\hline LOMBARDY & $1.99^{* *}$ & & $3.76^{* * *}$ \\
\hline VENETO & $2.72^{* * *}$ & & $4.96 * * *$ \\
\hline EMILIA-ROMAGNA & $2.09 * * *$ & & $4.40^{* * *}$ \\
\hline TUSCANY & $2.12^{* *}$ & & $5.03^{* * *}$ \\
\hline ABRUZZO & & & 0.21 \\
\hline UMBRIA & & & 3.87 \\
\hline MARCHE & $1.70^{* *}$ & & $-0.20 * * *$ \\
\hline LAZIO & & & 0.68 \\
\hline APULIA & 0.40 & & $0.10^{* * *}$ \\
\hline CAMPANIA & $2.30 * * *$ & & $-0.52 * * *$ \\
\hline LIGURIA & & -0.38 & $4.56^{* * *}$ \\
\hline TRENTINO-ALTO ADIGE & & $0.15^{* * *}$ & 0.54 \\
\hline FRIULI-VENEZIA GIULIA & & -0.30 & $-0.20 * *$ \\
\hline CALABRIA & & -0.08 & -0.11 \\
\hline SICILY & & $0.86^{* * *}$ & $0.51^{* *}$ \\
\hline SARDINIA & & -0.01 & 0.10 \\
\hline \multicolumn{4}{|c|}{ Time Effects } \\
\hline DYEAR01 & $0.77^{* * *}$ & -0.09 & $0.23^{* * *}$ \\
\hline DYEAR02 & $0.54 * * *$ & 0.10 & $0.24^{*}$ \\
\hline DYEAR03 & $0.16^{* * *}$ & $-0.12^{* *}$ & $-0.05 * * *$ \\
\hline DYEAR04 & $0.22^{* * *}$ & $-0.06 * *$ & $-0.15^{* * *}$ \\
\hline DYEAR05 & $0.84^{* * *}$ & -0.05 & $-0.25 * * *$ \\
\hline DYEAR06 & $0.20 * * *$ & $-0.13^{* *}$ & $-0.14^{* * *}$ \\
\hline R-squared & 0.76 & 0.86 & 0.91 \\
\hline
\end{tabular}

Note: ${ }^{* * *},{ }^{* *}$ and $*$ indicate significance at $1 \%, 5 \%$ and $10 \%$ respectively.

Table 3: FDI flows - Comparison between some Northern African countries, North Africa and Africa - values in million Dollars at current prices

\begin{tabular}{|c|c|c|c|c|c|c|c|c|c|c|c|c|c|}
\hline & & 1996 & 1997 & 1998 & 1999 & 2000 & 2001 & 2002 & 2003 & 2004 & 2005 & 2006 & 2007 \\
\hline \multirow[t]{2}{*}{ Morocco } & Inward & 322 & 1,207 & 400 & 1,364 & 422 & 2,808 & 481 & 2,314 & 895 & 1,653 & 2,450 & 2,577 \\
\hline & Outward & 28 & 9 & 20 & 18 & 59 & 97 & 28 & 12 & 31 & 74 & 445 & 652 \\
\hline \multirow[t]{2}{*}{ Algeria } & Inward & 270 & 260 & 607 & 292 & 438 & 1,196 & 1,065 & 634 & 882 & 1,081 & 1,795 & 1,665 \\
\hline & Outward & 0 & 0 & 1 & 47 & 18 & 9 & 100 & 14 & 258 & 23 & 35 & 290 \\
\hline \multirow[t]{2}{*}{ Tunisia } & Inward & 351 & 365 & 668 & 368 & 779 & 486 & 821 & 584 & 639 & 782 & 3,312 & 1,618 \\
\hline & Outward & 2 & 9 & 2 & 3 & 0 & 6 & 7 & 5 & 4 & 13 & 33 & 20 \\
\hline \multirow[t]{2}{*}{ Egypt } & Inward & 636 & 887 & 1,076 & 1,065 & 1,235 & 510 & 647 & 237 & 2,157 & 5,376 & 10,043 & 11,578 \\
\hline & Outward & 5 & 166 & 46 & 38 & 51 & 12 & 28 & 21 & 159 & 92 & 148 & 665 \\
\hline \multirow[t]{2}{*}{ North Africa * } & Inward & 1,468 & 2,749 & 2,973 & 3,332 & 3,408 & 5,461 & 3,873 & 5,262 & 6,441 & 12,235 & 23,155 & 22,415 \\
\hline & Outward & 99 & 468 & 364 & 331 & 226 & -50 & 26 & 115 & 166 & 329 & 134 & 1,159 \\
\hline \multirow[t]{2}{*}{ Africa ** } & Inward & 5,957 & 11,033 & 9,610 & 12,063 & 9,671 & 19,905 & 14,592 & 18,719 & 18,020 & 29,459 & 45,754 & 52,982 \\
\hline & Outward & 1,779 & 3,566 & 1,662 & 2,668 & 1,518 & $-3,031$ & 270 & 1,245 & 2,050 & 2,282 & 7,829 & 6,055 \\
\hline
\end{tabular}

Source: FDIStat, World Investment Report, 2008

Note: * Includes Algeria, Morocco, Western Sahara, Egypt, Sudan, Lybia, Tunisia

** Includes Angola, Benin, Botswana, Burkina Faso, Camerun, Capo Verde, Congo, Democratic Republic of Congo, Ivory Coast, Djbuti, Equatorial Guinea, Eritrea, Ethiopia, Gabon, Gambia, Ghana, Guinea, Guinea-Bissau, Kenya, Lesotho, Liberia, Madagascar, Mali, Mauritania, Mauritius, Mozambico, Namibia, Niger, Nigeria, Reunion, Ruanda, São Tomé and Principe, Senegal, Seychelles, Sierra Leone, Somalia, South Africa, Swaziland, Tanzania, Togo, Uganda, Zambia, Zimbabwe, Algeria, Morocco, Western Sahara, Egypt, Sudan, Lybia, Tunisia. 
Table 4: Percentage of FDI flows on gross capital formation - Comparison between some Northern African countries, North Africa (as a whole) and Africa

\begin{tabular}{|c|c|c|c|c|c|c|c|c|c|c|c|c|c|}
\hline & & 1996 & 1997 & 1998 & 1999 & 2000 & 2001 & 2002 & 2003 & 2004 & 2005 & 2006 & 2007 \\
\hline \multirow[t]{2}{*}{ Marocco } & Inward & 3,82 & 14,73 & 4,28 & 13,67 & 4,39 & 29,96 & 4,72 & 18,41 & 5,95 & 9,83 & 12,99 & n.a. \\
\hline & Outward & 0,33 & 0,11 & 0,22 & 0,18 & 0,61 & 1,04 & 0,28 & 0,10 & 0,20 & 0,44 & 2,36 & n.a. \\
\hline \multirow[t]{2}{*}{ Algeria } & Inward & 2,31 & 2,35 & 4,89 & 2,46 & 3,87 & 9,57 & 7,64 & 3,88 & 4,30 & 4,73 & 6,27 & n.a. \\
\hline & Outward & 0,00 & 0,00 & 0,01 & 0,40 & 0,16 & 0,07 & 0,72 & 0,09 & 1,26 & 0,10 & 0,12 & n.a. \\
\hline \multirow[t]{2}{*}{ Tunisia } & Inward & 7,73 & 7,84 & 13,56 & 6,95 & 15,42 & 9,28 & 15,35 & 9,98 & 9,96 & 12,07 & 48,63 & n.a. \\
\hline & Outward & 0,05 & 0,20 & 0,04 & 0,05 & 0,01 & 0,11 & 0,12 & 0,09 & 0,07 & 0,19 & 0,49 & n.a. \\
\hline \multirow[t]{2}{*}{ Egitto } & Inward & 4,51 & 5,92 & 6,37 & 6,22 & 7,28 & 3,40 & 4,37 & 1,79 & 16,85 & 32,67 & 46,49 & n.a. \\
\hline & Outward & 0,03 & 1,11 & 0,27 & 0,22 & 0,30 & 0,08 & 0,19 & 0,16 & 1,24 & 0,56 & 0,69 & n.a. \\
\hline \multirow[t]{2}{*}{ North Africa } & Inward & 3,37 & 6,27 & 6,15 & 6,77 & 6,90 & 11,38 & 7,78 & 9,83 & 10,06 & 16,23 & 24,89 & n.a. \\
\hline & Outward & 0,23 & 1,10 & 0,78 & 0,70 & 0,48 & $-0,11$ & 0,06 & 0,23 & 0,28 & 0,47 & 0,14 & n.a. \\
\hline \multirow[t]{2}{*}{ Africa } & Inward & 6,10 & 10,91 & 9,19 & 11,83 & 9,55 & 20,34 & 14,51 & 15,18 & 11,78 & 16,35 & 21,30 & n.a. \\
\hline & Outward & 1,91 & 3,72 & 1,69 & 2,82 & 1,65 & $-3,33$ & 0,29 & 1,08 & 1,47 & 1,40 & 3,89 & n.a. \\
\hline
\end{tabular}

Source: FDIStat, World Investment Report, 2008

Table 5: FDI Stock - Comparison between some Northern African countries, North Africa (as a whole) and Africa values in million Dollars at current prices

\begin{tabular}{|c|c|c|c|c|c|c|c|c|c|c|c|c|c|}
\hline & & 1996 & 1997 & 1998 & 1999 & 2000 & 2001 & 2002 & 2003 & 2004 & 2005 & 2006 & 2007 \\
\hline \multirow[t]{2}{*}{ Morocco } & Inward & 5,448 & 6,655 & 7,056 & 8,419 & 8,842 & 11,649 & 12,131 & 17,106 & 19,883 & 20,752 & 29,939 & 32,516 \\
\hline & Outward & 297 & 306 & 326 & 344 & 402 & 499 & 453 & 560 & 676 & 666 & 1,350 & 2,002 \\
\hline \multirow[t]{2}{*}{ Algeria } & Inward & 1,901 & 2,161 & 2,768 & 3,059 & 3,497 & 4,693 & 5,758 & 6,392 & 7,274 & 8,355 & 10,151 & 11,815 \\
\hline & Outward & 183 & 183 & 184 & 231 & 249 & 258 & 358 & 372 & 630 & 652 & 687 & 977 \\
\hline \multirow[t]{2}{*}{ Tunisia } & Inward & 11,181 & 10,629 & 12,237 & 11,432 & 11,545 & 11,520 & 13,861 & 16,229 & 17,844 & 16,840 & 21,853 & 26,223 \\
\hline & Outward & 29 & 32 & 34 & 33 & 33 & 32 & 37 & 43 & 47 & 52 & 89 & 118 \\
\hline \multirow[t]{2}{*}{ Egypt } & Inward & 15,326 & 16,578 & 17,654 & 18,719 & 19,955 & 20,465 & 21,112 & 21,349 & 23,506 & 28,882 & 38,925 & 50,503 \\
\hline & Outward & 355 & 521 & 566 & 604 & 655 & 668 & 696 & 716 & 875 & 967 & 1,116 & 1,781 \\
\hline \multirow[t]{2}{*}{ North Africa } & Inward & 34,676 & 36,874 & 40,787 & 42,945 & 45,688 & 50,637 & 56,029 & 65,736 & 75,035 & 84,700 & 116,293 & 141,460 \\
\hline & Outward & 1,902 & 2,365 & 2,729 & 3,056 & 3,282 & 3,224 & 3,175 & 3,385 & 3,636 & 3,874 & 4,243 & 5,400 \\
\hline \multirow[t]{2}{*}{ Africa } & Inward & 90,157 & 100,194 & 108,657 & 152,668 & 152,614 & 149,561 & 164,652 & 202,233 & 240,887 & 270,984 & 335,435 & 393,429 \\
\hline & Outward & 32,884 & 32,722 & 36,007 & 43,391 & 44,156 & 29,194 & 34,066 & 40,384 & 52,655 & 52,487 & 66,762 & 72,752 \\
\hline
\end{tabular}

Source: FDIStat, World Investment Report, 2008

Table 6: Percentage of FDI stock on GDP - Comparison between some Northern African countries, North Africa (as a whole) and Africa

\begin{tabular}{llcccccccccccc}
\hline & & 1996 & 1997 & 1998 & 1999 & 2000 & 2001 & 2002 & 2003 & 2004 & 2005 & 2006 & 2007 \\
\hline Morocco & Inward & 13.31 & 17.82 & 17.63 & 21.18 & 23.86 & 30.85 & 29.97 & 34.34 & 35.26 & 35.2 & 45.8 & 44.09 \\
\multirow{4}{*}{ Algeria } & Outward & 0.72 & 0.82 & 0.81 & 0.86 & 1.09 & 1.32 & 1.12 & 1.12 & 1.2 & 1.13 & 2.06 & 2.71 \\
& Inward & 4.05 & 4.49 & 5.74 & 6.29 & 6.38 & 8.51 & 10.11 & 9.4 & 8.55 & 8.16 & 8.75 & 8.96 \\
Tunisia & Outward & 0.39 & 0.38 & 0.38 & 0.48 & 0.45 & 0.47 & 0.63 & 0.55 & 0.74 & 0.64 & 0.59 & 0.74 \\
& Inward & 57.08 & 56.25 & 61.76 & 54.96 & 59.38 & 57.69 & 65.85 & 64.93 & 63.23 & 58.56 & 71.24 & 75.62 \\
\multirow{4}{*}{ Egypt } & Outward & 0.15 & 0.17 & 0.17 & 0.16 & 0.17 & 0.16 & 0.17 & 0.17 & 0.17 & 0.18 & 0.29 & 0.34 \\
\multirow{4}{*}{ North Africa } & Inward & 19.91 & 19.52 & 19.46 & 19.57 & 20.04 & 21.67 & 23.44 & 27.69 & 28.52 & 28.49 & 35.36 & 38.11 \\
& Outward & 0.46 & 0.61 & 0.62 & 0.63 & 0.66 & 0.71 & 0.77 & 0.93 & 1.06 & 0.95 & 1.01 & 1.34 \\
Africa & Inward & 15.72 & 15.99 & 17.29 & 17.53 & 17.8 & 20.23 & 22.99 & 25.47 & 25.02 & 23.91 & 28.59 & 29.84 \\
& Outward & 0.9 & 1.07 & 1.21 & 1.3 & 1.34 & 1.36 & 1.39 & 1.4 & 1.29 & 1.18 & 1.04 & 1.14 \\
& Inward & 16.07 & 17.19 & 18.91 & 26.24 & 25.21 & 25.63 & 28.28 & 29.13 & 29.15 & 27.92 & 30.64 & 31.27 \\
& Outward & 6.21 & 5.98 & 6.66 & 8.03 & 7.94 & 5.34 & 6.27 & 6.18 & 6.88 & 5.88 & 6.45 & 6.09 \\
\hline
\end{tabular}

Source: FDIStat, World Investment Report, 2008 
Table 7: Number of foreign firms participated by Italian firms

\begin{tabular}{lccccccc}
\hline & 1.1 .2002 & 1.1 .2003 & 1.1 .2004 & 1.1 .2005 & 1.1 .2006 & 1.1 .2007 & 1.1 .2008 \\
\hline Algeria & 86 & 87 & 91 & 94 & 95 & 95 & 97 \\
Morocco & 104 & 107 & 110 & 113 & 114 & 115 & 120 \\
Tunisia & 251 & 253 & 260 & 267 & 269 & 283 & 295 \\
Egypt & 87 & 91 & 97 & 99 & 100 & 103 & 106 \\
Total Northern Africa & 528 & 538 & 558 & 573 & 578 & 596 & 618 \\
\hline & & & & & & 2,061 & 2,123 \\
France & 1,869 & 1,890 & 1,950 & 1,992 & 2,004 & 1,394 & 1,633 \\
Spain & 1,193 & 1,218 & 1,287 & 1,325 & 1,342 & 1,683 & 1,743 \\
Germany & 1,462 & 1,527 & 1,557 & 1,608 & 1,619 & & \\
\hline Brazil & & & & & & 665 & 710 \\
Russia & 620 & 635 & 657 & 654 & 659 & 317 & 334 \\
India & 235 & 245 & 254 & 266 & 301 & 263 & 269 \\
China & 195 & 204 & 217 & 226 & 238 & 256 & 975 \\
\hline
\end{tabular}

Source: ICE - Reprint Milan Polytechnic

Table 8: Employees of foreign firms participated by Italian firms

\begin{tabular}{lccccccc}
\hline & 1.1 .2002 & 1.1 .2003 & 1.1 .2004 & 1.1 .2005 & 1.1 .2006 & 1.1 .2007 & 1.1 .2008 \\
\hline Algeria & 1,612 & 1,632 & 1,748 & 1,788 & 1,832 & 1,855 & 1,887 \\
Morocco & 10,061 & 10,271 & 10,654 & 11,102 & 10,940 & 11,447 & 11,548 \\
Tunisia & 18,592 & 18,990 & 19,128 & 19,094 & 19,193 & 20,034 & 20,844 \\
Egypt & 5,080 & 5,261 & 5,356 & 5,370 & 9,923 & 8,555 & 8,302 \\
Totale Northern Africa & 35,345 & 36,154 & 36,886 & 37,354 & 41,888 & 41,891 & 42,581 \\
& & & & & & & \\
France & 156,562 & 133,585 & 132,619 & 134,176 & 134,354 & 136,871 & 137,642 \\
Spain & 68,479 & 64,433 & 65,960 & 66,078 & 57,226 & 58,577 & 73,971 \\
Germany & 79,913 & 92,659 & 92,307 & 94,987 & 94,263 & 99,420 & 95,248 \\
& & & & & & 67,420 & 76,748 \\
Brazil & & & & & \\
Russia & 90,363 & 84,788 & 79,832 & 65,042 & 68,296 & 67,087 & 32,372 \\
India & 28,597 & 28,446 & 27,875 & 29,364 & 30,316 & 28,087 \\
China & 13,150 & 13,320 & 14,396 & 14,237 & 14,112 & 14,495 & 15,154 \\
\hline
\end{tabular}

Source: ICE - Reprint Milan Polytechnic

Table 9: Turnover of foreign firms participated by Italian firms (data expressed in million of Euros)

\begin{tabular}{lccccccc}
\hline & 1.1 .2002 & 1.1 .2003 & 1.1 .2004 & 1.1 .2005 & 1.1 .2006 & 1.1 .2007 & 1.1 .2008 \\
\hline Algeria & 442 & 707 & 693 & 825 & 1,671 & 1,931 & 2,050 \\
Morocco & 635 & 654 & 628 & 685 & 767 & 937 & 1,030 \\
Tunisia & 1,046 & 1,334 & 1,365 & 1,440 & 1,512 & 1,607 & 1,748 \\
Egypt & 1,652 & 1,744 & 1,448 & 1,707 & 2,629 & 3,027 & 3,234 \\
Total Northern Africa & 3,774 & 4,439 & 4,135 & 4,658 & 6,578 & 7,503 & 8,063 \\
\hline & & & & & & 50,104 & 53,336 \\
France & 48,101 & 41,654 & 43,207 & 46,901 & 48,458 & 26,864 & 52,295 \\
Spain & 20,135 & 17,907 & 20,602 & 23,066 & 23,367 & 46,922 & 49,693 \\
Germany & 36,687 & 34,928 & 35,230 & 39,205 & 42,547 & & \\
\hline & & & & & & 13,542 & 22,062 \\
Brazil & 16,885 & 12,774 & 12,713 & 11,772 & 13,875 & 16,542 \\
Russia & 1,736 & 1,832 & 2,036 & 2,257 & 2,558 & 4,691 & 4,321 \\
India & 951 & 981 & 1,025 & 1,082 & 1,178 & 1,250 & 1,419 \\
China & 2,465 & 2,816 & 2,883 & 3,354 & 4,123 & 4,722 & 4,959 \\
\hline
\end{tabular}

Source: ICE - Reprint Milan Polytechnic 
Table 10: Turnover per employee of foreign firms participated by Italian firms (values in Euros)

\begin{tabular}{lccccccc}
\hline & 1.1 .2002 & 1.1 .2003 & 1.1 .2004 & 1.1 .2005 & 1.1 .2006 & 1.1 .2007 & 1.1 .2008 \\
\hline Algeria & 273,883 & 433,272 & 396,625 & 461,633 & 912,118 & $1,041,132$ & $1,086,486$ \\
Morocco & 63,095 & 63,645 & 58,907 & 61,701 & 70,082 & 81,856 & 89,228 \\
Tunisia & 56,272 & 70,253 & 71,382 & 75,427 & 78,758 & 80,234 & 83,837 \\
Egypt & 325,098 & 331,572 & 270,407 & 317,952 & 264,920 & 353,840 & 389,593 \\
Total Northern Africa & 106,776 & 122,789 & 112,091 & 124,699 & 157,040 & 179,103 & 189,345 \\
& & & & & & & \\
France & 307,233 & 311,816 & 325,796 & 349,546 & 360,672 & 366,064 & 387,497 \\
Spain & 294,032 & 277,912 & 312,339 & 349,066 & 408,327 & 458,603 & 706,964 \\
Germany & 459,082 & 376,947 & 381,658 & 412,739 & 451,369 & 471,961 & 521,720 \\
& & & & & & & \\
Brazil & 186,856 & 150,652 & 159,252 & 180,992 & 203,154 & 245,362 & 287,458 \\
Russia & 60,692 & 64,392 & 73,055 & 76,853 & 84,368 & 167,017 & 133,470 \\
India & 72,327 & 73,679 & 71,221 & 75,999 & 83,503 & 86,202 & 93,619 \\
China & 78,324 & 76,321 & 72,009 & 73,215 & 78,349 & 79,809 & 81,268 \\
\hline
\end{tabular}

Source: ICE - Reprint Milan Polytechnic

Table 11: Investment and Disinvestment flows - Veneto Region - values in thousand Euros at current prices

\begin{tabular}{|c|c|c|c|c|c|c|c|c|c|c|c|c|c|c|}
\hline Region & Country & Type of flow & 1997 & 1998 & 1999 & 2000 & 2001 & 2002 & 2003 & 2004 & 2005 & 2006 & 2007 & Total \\
\hline \multirow[t]{12}{*}{ Veneto } & Algeria & Disinvestment & 0 & 0 & 0 & 0 & -128 & 0 & 0 & 0 & 0 & 0 & 0 & -128 \\
\hline & & Investment & 0 & 54 & 40 & 0 & 0 & 0 & 198 & 15 & 0 & 0 & 0 & 307 \\
\hline & Total Algeria & & 0 & 54 & 40 & 0 & -128 & 0 & 198 & 15 & 0 & 0 & 0 & 179 \\
\hline & Egypt & Disinvestment & 0 & 0 & -27 & 0 & 0 & 0 & 0 & 0 & -242 & -53 & -18 & -340 \\
\hline & & Investment & 114 & 227 & 405 & 424 & 733 & 221 & 725 & 728 & 2,191 & 263 & 6,174 & 12,205 \\
\hline & Total Egypt & & 114 & 227 & 378 & 424 & 733 & 221 & 725 & 728 & 1,949 & 210 & 6,156 & 11,865 \\
\hline & Morocco & Disinvestment & 0 & 0 & 0 & 0 & 0 & 0 & 0 & 0 & -15 & 0 & -15 & -30 \\
\hline & & Investment & 180 & 20 & 461 & 39 & 1,464 & 343 & 1,018 & 285 & 4,142 & 656 & 6,059 & 14,667 \\
\hline & Total Morocco & & 180 & 20 & 461 & 39 & 1,464 & 343 & 1,018 & 285 & 4,127 & 656 & 6,044 & 14,637 \\
\hline & Tunisia & Disinvestment & 0 & 0 & 0 & -129 & 0 & -68 & -34 & -80 & -51 & -20 & -53 & -435 \\
\hline & & Investment & 864 & 504 & 200 & 777 & 1,709 & 533 & 4,141 & 736 & 2,680 & 5,477 & 2,593 & 20,214 \\
\hline & Total Tunisia & & 864 & 504 & 200 & 648 & 1,709 & 465 & 4,107 & 656 & 2,629 & 5,457 & 2,540 & 19,779 \\
\hline Total Veneto & & & 1,158 & 805 & 1,079 & 1,111 & 3,778 & 1,029 & 6,048 & 1,684 & 8,705 & 6,323 & 14,740 & 46,460 \\
\hline
\end{tabular}

Source: Surveys and Elaborations Service - Department on Foreign Statistics - Bank of Italy

Table 12: Investment and Disinvestment flows - Veneto Region - values in thousand Euros at current prices

\begin{tabular}{|c|c|c|c|c|c|c|c|c|c|c|c|c|c|}
\hline Region & Country & Type of flow & 1998 & 1999 & 2000 & 2001 & 2002 & 2003 & 2004 & 2005 & 2006 & 2007 & Total \\
\hline \multirow{9}{*}{ Campania } & Egypt & Disinvestment & 0 & 0 & 0 & -44 & 0 & 0 & 0 & 0 & 0 & 0 & -44 \\
\hline & & Investment & 20 & 4 & 0 & 0 & 229 & 0 & 0 & 305 & 723 & 336 & 1,617 \\
\hline & Total Egypt & & 20 & 4 & 0 & -44 & 229 & 0 & 0 & 305 & 723 & 336 & 1,573 \\
\hline & Morocco & Disinvestment & 0 & 0 & 0 & 0 & 0 & 0 & 0 & -49 & 0 & 0 & -49 \\
\hline & & Investment & 0 & 31 & 0 & 15 & 83 & 0 & 0 & 275 & 93 & 265 & 762 \\
\hline & Total Morocco & & 0 & 31 & 0 & 15 & 83 & 0 & 0 & 226 & 93 & 265 & 713 \\
\hline & Tunisia & Disinvestment & 0 & 0 & 0 & 0 & 0 & 0 & 0 & $-1,138$ & 0 & 0 & $-1,138$ \\
\hline & & Investment & 112 & 33 & 62 & 0 & 55 & 259 & 113 & 80 & 356 & 1,044 & 2,114 \\
\hline & Total Tunisia & & 112 & 33 & 62 & 0 & 55 & 259 & 113 & $-1,058$ & 356 & 1,044 & 976 \\
\hline Total Campania & & & 132 & 68 & 62 & -29 & 367 & 259 & 113 & -527 & 1,172 & 1,645 & 3,262 \\
\hline
\end{tabular}

Source: Surveys and Elaborations Service - Department on Foreign Statistics - Bank of Italy 
Table 13: Investment and Disinvestment flows - Veneto Region - values in thousand Euros at current prices

\begin{tabular}{llllllllllllllll}
\hline Region & Country & Type of flow & 1997 & 1999 & 2000 & 2001 & 2002 & 2003 & 2004 & 2005 & 2006 & 2007 & Total of period \\
Apulia & Egypt & Disinvestment & 0 & 0 & 0 & 0 & 0 & 0 & 0 & 0 & -85 & 0 & -85 \\
& & Investment & 0 & 106 & 136 & 103 & 115 & 49 & 81 & 89 & 103 & 120 & 902 \\
& & & 0 & 106 & 136 & 103 & 115 & 49 & 81 & 89 & 18 & 120 & 817 \\
& Total Egypt & & & 0 & -26 & 0 & 0 & 0 & 0 & 0 & -685 & 0 & -40 & -751 \\
& Morocco & Disinvestment & 0 & Investment & 0 & 0 & 11 & 151 & 487 & 91 & 126 & 20 & 61 & 358 & 1,305 \\
& & & 0 & -26 & 11 & 151 & 487 & 91 & 126 & -665 & 61 & 318 & 554 \\
& \multirow{2}{*}{ Total Morocco } & & -25 & 0 & 0 & 0 & 0 & 0 & -20 & 0 & 0 & -30 & -75 \\
& Tunisia & Disinvestment & -25 & Investment & 74 & 0 & 0 & 12 & 114 & 0 & 149 & 257 & 0 & 130 & 736 \\
& & 49 & 0 & 0 & 12 & 114 & 0 & 129 & 257 & 0 & 100 & 661 \\
Total Apulia & Total Tunisia & & 49 & 80 & 147 & 266 & 716 & 140 & 336 & -319 & 79 & 538 & 2,032 \\
\hline
\end{tabular}

Source: Surveys and Elaborations Service - Department on Foreign Statistics - Bank of Italy

Table 14: Investment and Disinvestment flows - Apulia Region - values in thousand Euros at current prices

\begin{tabular}{lllcccccc}
\hline Region & Country & Type of flow & 1997 & 1999 & 2005 & 2006 & 2007 & Total \\
Calabria & Egypt & Investment & 0 & 1 & 0 & 0 & 133 & 134 \\
& Total Egypt & & 0 & 1 & 0 & 0 & 133 & 134 \\
& Morocco & Investment & 0 & 0 & 15 & 0 & 0 & 15 \\
& Total Morocco & & 0 & 0 & 15 & 0 & 0 & 15 \\
& Tunisia & Investment & 169 & 77 & 0 & 50 & 73 & 369 \\
& Total Tunisia & & 169 & 77 & 0 & 50 & 73 & 369 \\
\multicolumn{1}{l}{ Total Calabria } & & & 169 & 78 & 15 & 50 & 206 & 518 \\
\hline
\end{tabular}

Source: Surveys and Elaborations Service - Department on Foreign Statistics - Bank of Italy

Table 15: Investment and Disinvestment flows - Sicily Region - values in thousand Euros at current prices

\begin{tabular}{|c|c|c|c|c|c|c|c|c|c|c|c|c|c|c|}
\hline Region & Country & Type of flow & 1997 & 1998 & 1999 & 2000 & 2001 & 2002 & 2003 & 2004 & 2005 & 2006 & 2007 & Total \\
\hline \multirow[t]{10}{*}{ Sicily } & Algeria & Investment & 0 & 0 & 0 & 0 & 0 & 0 & 0 & 0 & 0 & 0 & 107 & 107 \\
\hline & Total Algeria & & 0 & 0 & 0 & 0 & 0 & 0 & 0 & 0 & 0 & 0 & 107 & 107 \\
\hline & Egypt & Investment & 12 & 0 & 23 & 0 & 0 & 0 & 91 & 84 & 121 & 73 & 105 & 509 \\
\hline & Total Egypt & & 12 & 0 & 23 & 0 & 0 & 0 & 91 & 84 & 121 & 73 & 105 & 509 \\
\hline & Morocco & Disinvestment & 0 & 0 & 0 & 0 & 0 & -35 & 0 & 0 & 0 & 0 & -55 & -90 \\
\hline & & Investment & 0 & 81 & 0 & 325 & 307 & 123 & 0 & 130 & 0 & 944 & 1,729 & 3,639 \\
\hline & Total Morocco & & 0 & 81 & 0 & 325 & 307 & 88 & 0 & 130 & 0 & 944 & 1,674 & 3,549 \\
\hline & Tunisia & Disinvestment & -49 & -19 & 0 & 0 & 0 & 0 & 0 & 0 & 0 & -20 & 0 & -88 \\
\hline & & Investment & 838 & 474 & 248 & 1,489 & 665 & 290 & 138 & 238 & 346 & 2,023 & 3,317 & 10,066 \\
\hline & Total Tunisia & & 789 & 455 & 248 & 1,489 & 665 & 290 & 138 & 238 & 346 & 2,003 & 3,317 & 9,978 \\
\hline Total Sicily & & & 801 & 536 & 271 & 1,814 & 972 & 378 & 229 & 452 & 467 & 3,020 & 5,203 & 14,143 \\
\hline
\end{tabular}

Table 16: Investment and Disinvestment flows - Abruzzo Region - values in thousand Euros at current prices

\begin{tabular}{|c|c|c|c|c|c|c|c|c|c|c|c|c|c|c|}
\hline Region & Country & Type of flow & 1997 & 1998 & 1999 & 2000 & 2001 & 2002 & 2003 & 2004 & 2005 & 2006 & 2007 & Total of period \\
\hline \multirow{10}{*}{ Abruzzo } & Algeria & Investment & 0 & 0 & 0 & 0 & 0 & 0 & 0 & 0 & 0 & 0 & 34 & 34 \\
\hline & Total Algeria & & 0 & 0 & 0 & 0 & 0 & 0 & 0 & 0 & 0 & 0 & 34 & 34 \\
\hline & Egypt & Investment & 0 & 58 & 0 & 0 & 0 & 0 & 17 & 14 & 91 & 0 & 121 & 301 \\
\hline & Total Egypt & & 0 & 58 & 0 & 0 & 0 & 0 & 17 & 14 & 91 & 0 & 121 & 301 \\
\hline & Morocco & Disinvestment & 0 & 0 & 0 & -27 & 0 & 0 & 0 & -99 & 0 & 0 & 0 & -126 \\
\hline & & Investment & 0 & 0 & 20 & 103 & 0 & 0 & 20 & 114 & 16 & 125 & 140 & 538 \\
\hline & Total Morocco & & 0 & 0 & 20 & 76 & 0 & 0 & 20 & 15 & 16 & 125 & 140 & 412 \\
\hline & Tunisia & Disinvestment & 0 & -31 & -913 & 0 & $-1,061$ & 0 & 0 & 0 & -45 & -50 & -110 & -2.21 \\
\hline & & Investment & 309 & 1,263 & 974 & 36 & 0 & 222 & 0 & 371 & 15 & 8,308 & 512 & 12.01 \\
\hline & Total Tunisia & & 309 & 1,232 & 61 & 36 & $-1,061$ & 222 & 0 & 371 & -30 & 8,258 & 402 & 9,800 \\
\hline Total Abruzzo & & & 309 & 1,290 & 81 & 112 & $-1,061$ & 222 & 37 & 400 & 77 & 8,383 & 697 & 10,547 \\
\hline
\end{tabular}

Source: Surveys and Elaborations Service - Department on Foreign Statistics - Bank of Italy 
Table 17: Investment and Disinvestment flows - Basilicata Region - values in thousand Euros at current prices

\begin{tabular}{lllccccccc}
\hline Region & Country & Type of flow & 1999 & 2002 & 2005 & 2006 & 2007 & Total \\
Basilicata & Egypt & Investment & 18 & 0 & 15 & 0 & 0 & 33 \\
& Total Egypt & & 18 & 0 & 15 & 0 & 0 & 33 \\
& Morocco & Investment & 0 & 217 & 0 & 0 & 0 & 217 \\
& Total Morocco & & 0 & 217 & 0 & 0 & 0 & 217 \\
& Tunisia & Investment & 0 & 0 & 0 & 54 & 50 & 104 \\
& Total Tunisia & & 0 & 0 & 0 & 54 & 50 & 104 \\
Total Basilicata & & & 18 & 217 & 15 & 54 & 50 & 354 \\
\hline
\end{tabular}

Source: Surveys and Elaborations Service - Department on Foreign Statistics - Bank of Italy

Table 18: Investment and Disinvestment flows - Lazio Region - values in thousand Euros at current prices

\begin{tabular}{|c|c|c|c|c|c|c|c|c|c|c|c|c|c|c|}
\hline Region & Country & Type of flow & 1997 & 1998 & 1999 & 2000 & 2001 & 2002 & 2003 & 2004 & 2005 & 2006 & 2007 & Total \\
\hline \multirow[t]{12}{*}{ Lazio } & Algeria & Disinvestment & 0 & 0 & 0 & 0 & 0 & 0 & 0 & 0 & 0 & $-16,147$ & $-2,128$ & $-18,275$ \\
\hline & & Investment & 0 & 12 & 0 & 0 & 0 & 710 & 0 & 165 & 3,500 & 0 & 0 & 4,387 \\
\hline & Total Algeria & & 0 & 12 & 0 & 0 & 0 & 710 & 0 & 165 & 3,500 & $-16,147$ & $-2,128$ & $-13,888$ \\
\hline & Egypt & Disinvestment & 0 & -44 & 0 & -13 & 0 & 0 & -103 & -50 & 0 & $-1,206$ & 0 & $-1,416$ \\
\hline & & Investment & 176 & 0 & 488 & 1,666 & 194 & 439 & 2,052 & 3,054 & 991 & 1,570 & 2,267 & 12,897 \\
\hline & Total Egypt & & 176 & -44 & 488 & 1,653 & 194 & 439 & 1,949 & 3,004 & 991 & 364 & 2,267 & 11,481 \\
\hline & Morocco & Disinvestment & 0 & 0 & -93 & 0 & -168 & 0 & 0 & 0 & 0 & -29 & 0 & -290 \\
\hline & & Investment & 0 & 273 & 13 & 229 & 315 & 26 & 0 & 325 & 269 & 2,386 & 545 & 4,381 \\
\hline & Total Morocco & & 0 & 273 & -80 & 229 & 147 & 26 & 0 & 325 & 269 & 2,357 & 545 & 4,091 \\
\hline & Tunisia & Disinvestment & 0 & 0 & 0 & -15 & -178 & 0 & 0 & 0 & 0 & -27 & -320 & -540 \\
\hline & & Investment & 192 & 0 & 1,089 & 870 & 621 & 336 & 356 & 1,115 & 9,451 & 2,697 & 2,971 & 19,698 \\
\hline & Total Tunisia & & 192 & 0 & 1,089 & 855 & 443 & 336 & 356 & 1,115 & 9,451 & 2,670 & 2,651 & 19,158 \\
\hline Total Lazio & & & 368 & 241 & 1,497 & 2,737 & 784 & 1,511 & 2,305 & 4,609 & 14,211 & $-10,756$ & 3,335 & 20,842 \\
\hline
\end{tabular}

Source: Surveys and Elaborations Service - Department on Foreign Statistics - Bank of Italy

Table 19: Investment and Disinvestment flows - Liguria Region - values in thousand Euros at current prices

\begin{tabular}{lllllllllllllll}
\hline Region & Country & Type of flow & 1997 & 1998 & 1999 & 2000 & 2001 & 2002 & 2003 & 2004 & 2005 & 2006 & 2007 & Total \\
Liguria & Algeria & Disinvestment & 0 & 0 & 0 & 0 & $-1,181$ & -90 & 0 & 0 & 0 & 0 & -39 & -1.31 \\
& & Investment & 0 & 70 & 138 & 0 & 0 & 0 & 193 & 0 & 0 & 231 & 0 & 632 \\
& Total Algeria & & 0 & 70 & 138 & 0 & $-1,181$ & -90 & 193 & 0 & 0 & 231 & -39 & -678 \\
& Egypt & Disinvestment & 0 & 0 & 0 & -81 & 0 & 0 & 0 & 0 & 0 & 0 & 0 & -81 \\
& & Investment & 0 & 0 & 20 & 0 & 0 & 0 & 101 & 13 & 199 & 218 & 516 & 1.067 \\
& \multirow{2}{*}{ Total Egypt } & & 0 & 0 & 20 & -81 & 0 & 0 & 101 & 13 & 199 & 218 & 516 & 986 \\
& Morocco & Investment & 67 & 27 & 0 & 0 & 77 & 27 & 143 & 0 & 49 & 2,120 & 1,675 & 4.185 \\
& Total Morocco & & 67 & 27 & 0 & 0 & 77 & 27 & 143 & 0 & 49 & 2,120 & 1,675 & 4,185 \\
& Tunisia & Disinvestment & 0 & 0 & 0 & 0 & 0 & 0 & -51 & -20 & -26 & 0 & 0 & -97 \\
& & Investment & 14 & 190 & 21 & 59 & 51 & 15 & 0 & 301 & 60 & 1,470 & 822 & 3.003 \\
& \multirow{2}{*}{ Total Tunisia } & & 14 & 190 & 21 & 59 & 51 & 15 & -51 & 281 & 34 & 1,470 & 822 & 2,906 \\
Total Liguria & & & 81 & 287 & 179 & -22 & $-1,053$ & -48 & 386 & 294 & 282 & 4,039 & 2,974 & 7,399 \\
\hline
\end{tabular}

Source: Surveys and Elaborations Service - Department on Foreign Statistics - Bank of Italy 
Table 20: Investment and Disinvestment flows - Marche Region - values in thousand Euros at current prices

\begin{tabular}{lllllllllllllll}
\hline Region & Country & Type of flow & 1997 & 1998 & 1999 & 2000 & 2001 & 2002 & 2003 & 2004 & 2005 & 2006 & 2007 & Total \\
Marche & Algeria & Investment & 0 & 0 & 9,659 & 0 & 652 & 0 & 0 & 0 & 0 & 0 & 235 & 10.546 \\
& Total Algeria & & 0 & 0 & 9,659 & 0 & 652 & 0 & 0 & 0 & 0 & 0 & 235 & 10,546 \\
& Egypt & Disinvestment & 0 & 0 & 0 & 0 & 0 & 0 & 0 & 0 & 0 & 0 & -15 & -15 \\
& & Investment & 0 & 21 & 27 & 11 & 0 & 0 & 255 & 340 & 1,445 & 1,181 & 126 & 3.406 \\
& \multirow{2}{*}{ Total Egypt } & & 0 & 21 & 27 & 11 & 0 & 0 & 255 & 340 & 1,445 & 1,181 & 111 & 3.391 \\
& Morocco & Disinvestment & 0 & 0 & 0 & 0 & 0 & 0 & 0 & 0 & 0 & 0 & -31 & -31 \\
& & Investment & 0 & 41 & 52 & 0 & 0 & 116 & 40 & 20 & 207 & 118 & 674 & 1.268 \\
& \multirow{2}{*}{ Total Morocco } & & 0 & 41 & 52 & 0 & 0 & 116 & 40 & 20 & 207 & 118 & 643 & 1,237 \\
& Tunisia & Disinvestment & 0 & -188 & 0 & 0 & 0 & 0 & -50 & 0 & 0 & -27 & 0 & -265 \\
& & Investment & 16 & 0 & 18 & 20 & 207 & 775 & 76 & 89 & 56 & 0 & 1,467 & 2.724 \\
\multirow{2}{*}{ Total Marche } & Total Tunisia & & 16 & -188 & 18 & 20 & 207 & 775 & 26 & 89 & 56 & -27 & 1,467 & 2,459 \\
& & & 16 & -126 & 9,756 & 31 & 859 & 891 & 321 & 449 & 1,708 & 1,272 & 2,456 & 17,633 \\
\hline
\end{tabular}

Source: Surveys and Elaborations Service - Department on Foreign Statistics - Bank of Italy

Table 21: Investment and Disinvestment flows - Tuscany Region - values in thousand Euros at current prices

\begin{tabular}{|c|c|c|c|c|c|c|c|c|c|c|c|c|c|c|}
\hline $\begin{array}{l}\text { Region } \\
\text { Tuscany }\end{array}$ & Country & Type of flow & 1997 & 1998 & 1999 & 2000 & 2001 & 2002 & 2003 & 2004 & 2005 & 2006 & 2007 & Total \\
\hline \multirow[t]{11}{*}{ Tuscany } & Algeria & Investment & 12 & 0 & 0 & 0 & 10 & 12 & 0 & 0 & 0 & 0 & 0 & 34 \\
\hline & Total Algeria & & 12 & 0 & 0 & 0 & 10 & 12 & 0 & 0 & 0 & 0 & 0 & 34 \\
\hline & Egypt & Disinvestment & 0 & -45 & 0 & 0 & -117 & 0 & -52 & 0 & -25 & 0 & 0 & -239 \\
\hline & & Investment & 32 & 25 & 273 & 139 & 1,260 & 167 & 364 & 304 & 842 & 543 & 682 & 4.631 \\
\hline & Total Egypt & & 32 & -20 & 273 & 139 & 1,143 & 167 & 312 & 304 & 817 & 543 & 682 & 4,392 \\
\hline & Morocco & Disinvestment & 0 & 0 & 0 & 0 & 0 & 0 & -276 & 0 & -20 & 0 & 0 & -296 \\
\hline & & Investment & 444 & 283 & 164 & 455 & 387 & 197 & 113 & 125 & 137 & 165 & 686 & 3.156 \\
\hline & Total Morocco & & 444 & 283 & 164 & 455 & 387 & 197 & -163 & 125 & 117 & 165 & 686 & 2,860 \\
\hline & Tunisia & Disinvestment & -105 & 0 & -103 & 0 & -187 & 0 & 0 & -67 & $-2,728$ & -630 & -30 & -3.85 \\
\hline & & Investment & 138 & 317 & 150 & 129 & 468 & 1,045 & 83 & 114 & 1,063 & 300 & 252 & 4.059 \\
\hline & Total Tunisia & & 33 & 317 & 47 & 129 & 281 & 1,045 & 83 & 47 & $-1,665$ & -330 & 222 & 209 \\
\hline Total Tuscany & & & 521 & 580 & 484 & 723 & 1,821 & 1,421 & 232 & 476 & -731 & 378 & 1,590 & 7,495 \\
\hline
\end{tabular}

Source: Surveys and Elaborations Service - Department on Foreign Statistics - Bank of Italy

Table 22: Investment and Disinvestment flows - Lombardy Region - values in thousand Euros at current prices

\begin{tabular}{|c|c|c|c|c|c|c|c|c|c|c|c|c|c|c|}
\hline Region & Country & Type of flow & 1997 & 1998 & 1999 & 2000 & 2001 & 2002 & 2003 & 2004 & 2005 & 2006 & 2007 & Total \\
\hline \multirow[t]{12}{*}{ Lombardy } & Algeria & Disinvestment & -36 & 0 & 0 & 0 & 0 & -491 & 0 & -17 & 0 & 0 & 0 & -544 \\
\hline & & Investment & 0 & 115 & 0 & 62 & 38 & 187 & 0 & 366 & 51 & 65 & 414 & 1,298 \\
\hline & Total Algeria & & -36 & 115 & 0 & 62 & 38 & -304 & 0 & 349 & 51 & 65 & 414 & 754 \\
\hline & Egypt & Disinvestment & -12 & -371 & $-1,205$ & -144 & -212 & -85 & -57 & -53 & -426 & $-7,383$ & -177 & $-10,125$ \\
\hline & & Investment & 8,364 & 5,871 & 23,377 & 17,809 & 1,553 & 802 & 11,594 & 4,488 & 2,375 & 5,324 & 6,700 & 88,257 \\
\hline & Total Egypt & & 8,352 & 5,500 & 22,172 & 17,665 & 1,341 & 717 & 11,537 & 4,435 & 1,949 & $-2,059$ & 6,523 & 78,132 \\
\hline & Morocco & Disinvestment & 0 & 0 & -253 & -310 & -48 & -108 & -633 & -31 & $-3,076$ & -943 & 0 & $-5,402$ \\
\hline & & Investment & 188 & 268 & 1,980 & 1,009 & 953 & 1,185 & 1,035 & 1,222 & 5,309 & 4,178 & 2,694 & 20,021 \\
\hline & Total Morocco & & 188 & 268 & 1,727 & 699 & 905 & 1,077 & 402 & 1,191 & 2,233 & 3,235 & 2,694 & 14,619 \\
\hline & Tunisia & Disinvestment & 0 & 0 & -390 & -111 & -266 & -446 & -358 & -210 & -63 & -197 & -581 & $-2,622$ \\
\hline & & Investment & 1,614 & 4,502 & 4,142 & 3,829 & 5,682 & 1,391 & 3,299 & 2,999 & 1,653 & 2,754 & 6,421 & 38,286 \\
\hline & Total Tunisia & & 1,614 & 4,502 & 3,752 & 3,718 & 5,416 & 945 & 2,941 & 2,789 & 1,590 & 2,557 & 5,840 & 35,664 \\
\hline Total Lombardy & & & 10,118 & 10,385 & 27,651 & 22,144 & 7,700 & 2,435 & 14,880 & 8,764 & 5,823 & 3,798 & 15,471 & 129,169 \\
\hline
\end{tabular}


Table 23: Investment and Disinvestment flows - Piedmont Region - values in thousand Euros at current prices

\begin{tabular}{|c|c|c|c|c|c|c|c|c|c|c|c|c|c|c|}
\hline Region & Country & Type of flow & 1997 & 1998 & 1999 & 2000 & 2001 & 2002 & 2003 & 2004 & 2005 & 2006 & 2007 & Total \\
\hline \multirow[t]{12}{*}{ Piedmont } & Algeria & Disinvestment & 0 & 0 & 0 & 0 & -387 & 0 & 0 & 0 & 0 & 0 & 0 & -387 \\
\hline & & Investment & 0 & 0 & 0 & 46 & 0 & 4,500 & 270 & 0 & 0 & 15 & 0 & 4,831 \\
\hline & Total Algeria & & 0 & 0 & 0 & 46 & -387 & 4,500 & 270 & 0 & 0 & 15 & 0 & 4,444 \\
\hline & Egypt & Disinvestment & -379 & 0 & 0 & -41 & 0 & 0 & -43 & -120 & -51 & 0 & -116 & -750 \\
\hline & & Investment & 233 & 0 & 224 & 129 & 288 & 60 & 42 & 1,944 & 201 & 969 & 770 & 4,860 \\
\hline & Total Egypt & & -146 & 0 & 224 & 88 & 288 & 60 & -1 & 1,824 & 150 & 969 & 654 & 4,110 \\
\hline & Morocco & Disinvestment & 0 & 0 & 0 & 0 & 0 & 0 & -81 & 0 & 0 & -90 & -20 & -191 \\
\hline & & Investment & 1,523 & 120 & 169 & 452 & 97 & 2,258 & 408 & 458 & 2,792 & 2,269 & 1,365 & 11,911 \\
\hline & Total Morocco & & 1,523 & 120 & 169 & 452 & 97 & 2,258 & 327 & 458 & 2,792 & 2,179 & 1,345 & 11,720 \\
\hline & Tunisia & Disinvestment & -245 & -20 & -15 & $-1,110$ & 0 & 0 & -155 & 0 & -250 & -44 & -28 & $-1,867$ \\
\hline & & Investment & 1,176 & 845 & 2,234 & 1,486 & 177 & 4,156 & 210 & 1,524 & 694 & 2,405 & 3,593 & 18,500 \\
\hline & Total Tunisia & & 931 & 825 & 2,219 & 376 & 177 & 4,156 & 55 & 1,524 & 444 & 2,361 & 3,565 & 16,633 \\
\hline Total Piedmont & & & 2,308 & 945 & 2,612 & 962 & 175 & 10,974 & 651 & 3,806 & 3,386 & 5,524 & 5,564 & 36,907 \\
\hline
\end{tabular}

Table 24: Investment and Disinvestment flows - Emilia-Romagna Region - values in thousand Euros at current prices

\begin{tabular}{|c|c|c|c|c|c|c|c|c|c|c|c|c|c|c|}
\hline Region & Country & Type of flow & 1997 & 1998 & 1999 & 2000 & 2001 & 2002 & 2003 & 2004 & 2005 & 2006 & 2007 & Total \\
\hline \multirow[t]{12}{*}{ Emilia-Romagna } & Algeria & Disinvestment & 0 & 0 & 0 & 0 & 0 & 0 & 0 & 0 & 0 & -26 & 0 & -26 \\
\hline & & Investment & 64 & 79 & 31 & 27 & 58 & 135 & 230 & 341 & 116 & 175 & 2,550 & 3,806 \\
\hline & Total Algeria & & 64 & 79 & 31 & 27 & 58 & 135 & 230 & 341 & 116 & 149 & 2,550 & 3,780 \\
\hline & Egypt & Disinvestment & 0 & 0 & 0 & -32 & -71 & 0 & 0 & -150 & -108 & 0 & 0 & -361 \\
\hline & & Investment & 210 & 481 & 510 & 183 & 56 & 435 & 430 & 1,450 & 847 & 618 & 11,457 & 16,677 \\
\hline & Total Egypt & & 210 & 481 & 510 & 151 & -15 & 435 & 430 & 1,300 & 739 & 618 & 11,457 & 16,316 \\
\hline & Morocco & Disinvestment & 0 & 0 & 0 & 0 & 0 & 0 & 0 & 0 & 0 & -178 & $-2,125$ & $-2,303$ \\
\hline & & Investment & 10 & 0 & 431 & 139 & 645 & 309 & 179 & 182 & 461 & 860 & 584 & 3,800 \\
\hline & Total Morocco & & 10 & 0 & 431 & 139 & 645 & 309 & 179 & 182 & 461 & 682 & $-1,541$ & 1,497 \\
\hline & Tunisia & Disinvestment & 0 & -100 & -35 & 0 & 0 & -39 & 0 & 0 & 0 & 0 & -380 & -554 \\
\hline & & Investment & 105 & 87 & 515 & 581 & 501 & 961 & 346 & 442 & 610 & 1,790 & 1,667 & 7,605 \\
\hline & Total Tunisia & & 105 & -13 & 480 & 581 & 501 & 922 & 346 & 442 & 610 & 1,790 & 1,287 & 7,051 \\
\hline Total Emilia-Romagna & & & 389 & 547 & 1,452 & 898 & 1,189 & 1,801 & 1,185 & 2,265 & 1,926 & 3,239 & 13,753 & 28,644 \\
\hline
\end{tabular}

Source: Surveys and Elaborations Service - Department on Foreign Statistics - Bank of Italy

Table 25: Flow per employee of foreign firms participated by Italian firms - values in million Dollars at current prices

\begin{tabular}{lccccccc}
\hline & \multicolumn{6}{c}{ Flow per employee of foreign firms participated by Italian firms } \\
& 2001 & 2002 & 2003 & 2004 & 2005 & 2006 & 2007 \\
Egypt & 0.455 & 0.419 & 0.464 & 0.61 & 0.334 & 0.544 & 0.655 \\
Morocco & 0.125 & 0.124 & 0.144 & 0.158 & 0.171 & 0.185 & 0.245 \\
Tunisia & 0.182 & 0.177 & 0.212 & 0.264 & 0.278 & 0.294 & 0.352 \\
& & & & & & & \\
France & 0.362 & 0.446 & 0.537 & 0.617 & 0.627 & 0.659 & 0.757 \\
Spain & 0.368 & 0.432 & 0.543 & 0.641 & 0.774 & 0.846 & 0.807 \\
Germany & 0.977 & 0.858 & 1.039 & 1.18 & 1.229 & 1.301 & 1.597 \\
& & & & & & & \\
Brazil & 0.049 & 0.046 & 0.053 & 0.086 & 0.09 & 0.106 & 0.113 \\
Russia & 0.378 & 0.389 & 0.49 & 0.622 & 0.73 & 0.948 & 1.023 \\
India & 0.184 & 0.186 & 0.218 & 0.288 & 0.342 & 0.445 & 0.577 \\
China & 0.306 & 0.316 & 0.379 & 0.442 & 0.443 & 0.501 & 0.628 \\
\hline
\end{tabular}

Source: our elaboration on ICE - Reprint Milan Polytechnic, Comext and World Bank data 
Figure 1: Percentage of inward flows on gross capital formation

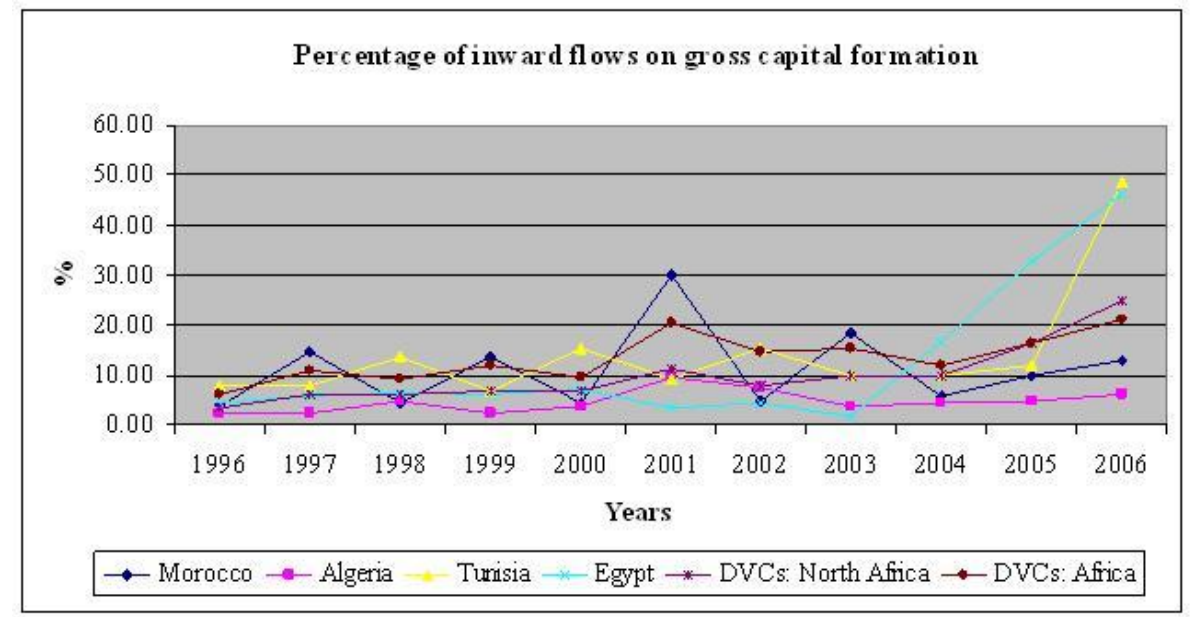

Source: FDIStat, World Investment Report, 2008

Figure 2: Stock of inward FDI: a Comparison

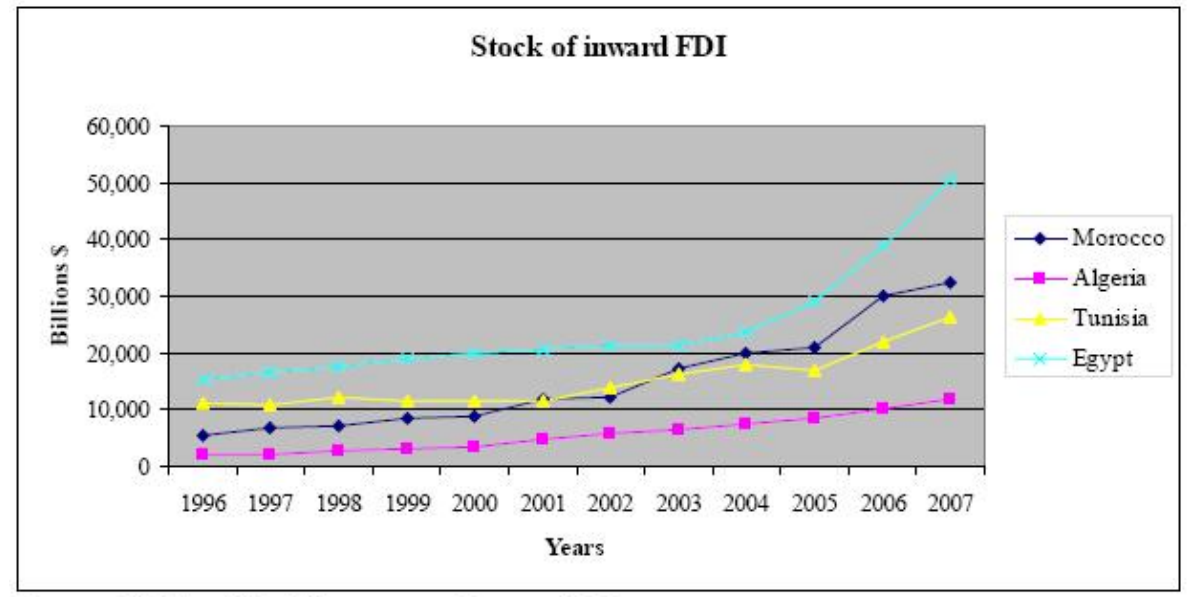

Source: FDIStat, World Investment Report, 2008

Figure 3: Percentage of inward FDI on GDP

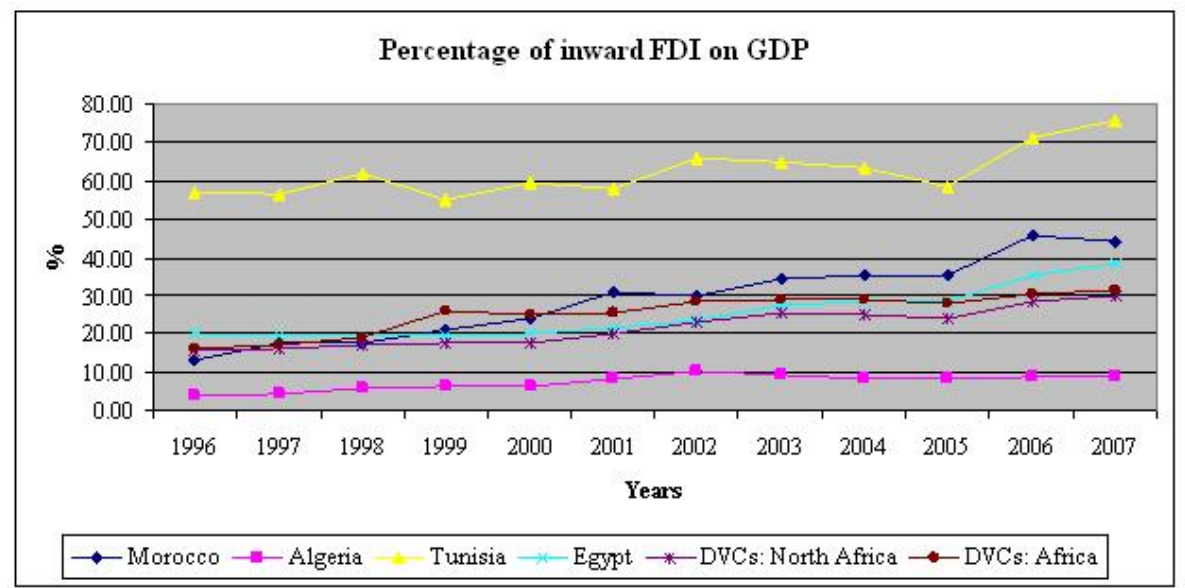

Source: FDIStat, World Investment Report, 2008 
Figure 4: Foreign firms participated by Italian firms

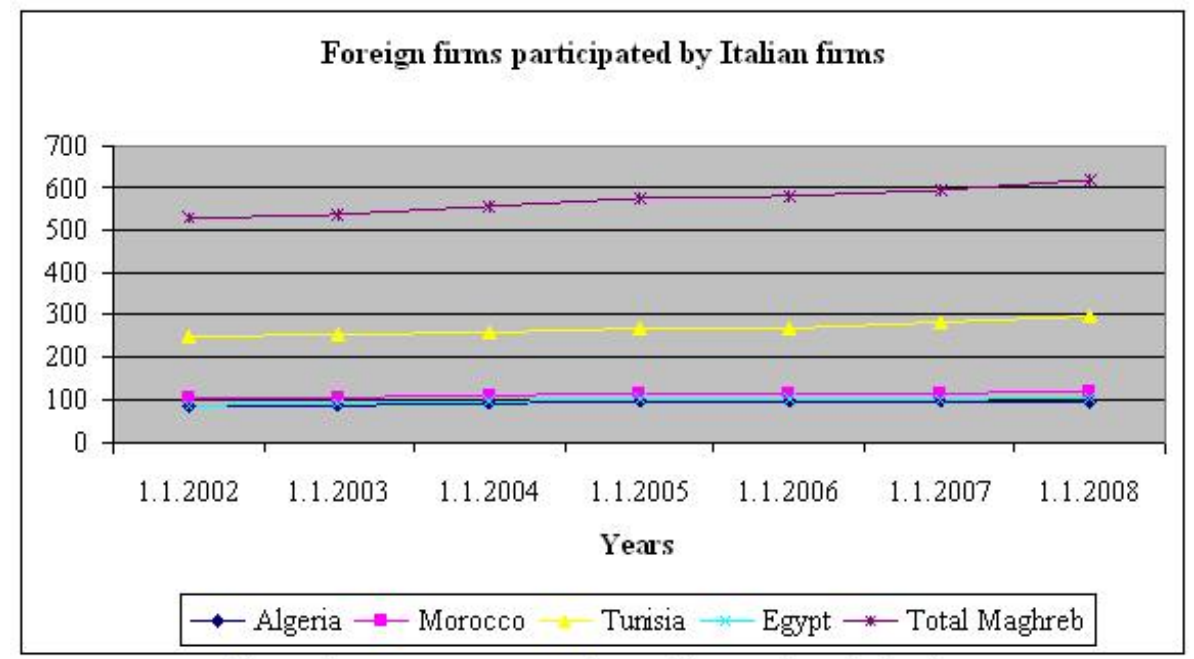

Source: our elaboration on ICE - Reprint Milan Polytechnic data

Figure 5: Employees of foreign firms participated by Italian firms

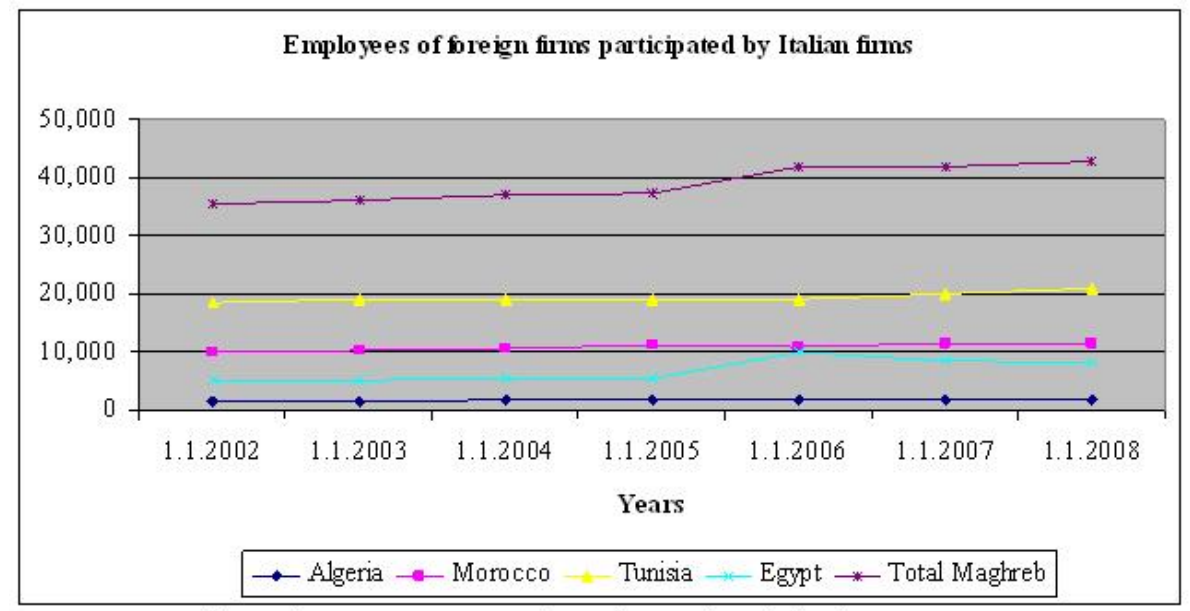

Source: our elaboration on ICE - Reprint Milan Polytechnic data

Figure 6: Turnover of foreign firms participated by Italian firms

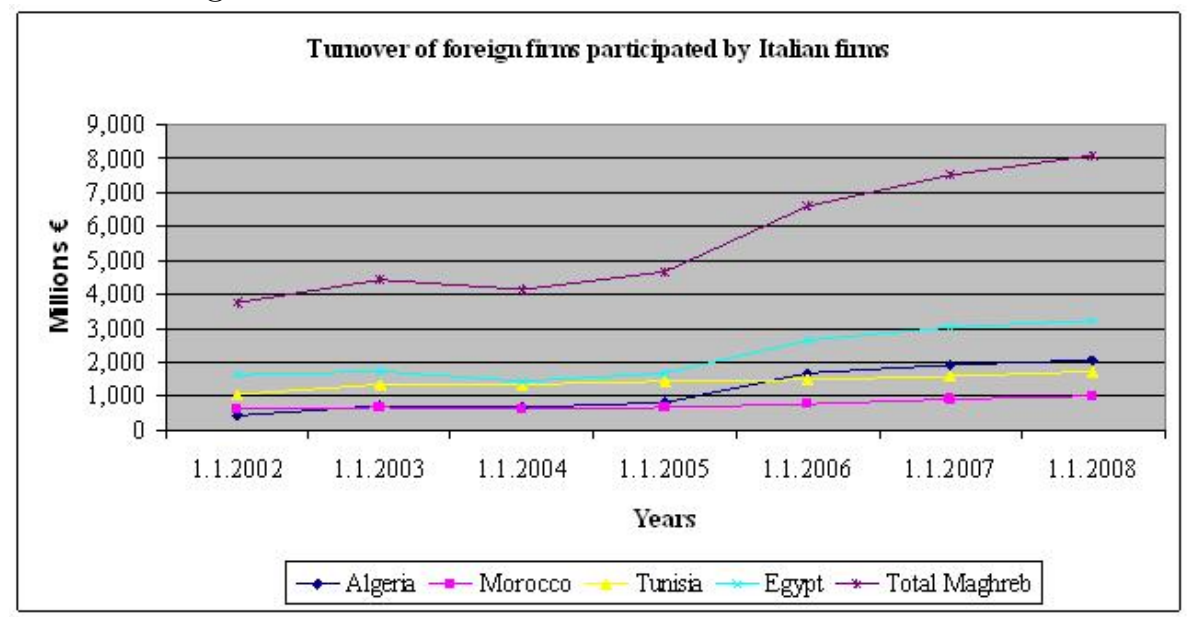

Source: our elaboration on ICE - Reprint Milan Polytechnic data 
Figure 7: Turnover per employee of foreign firms participated by Italian firms

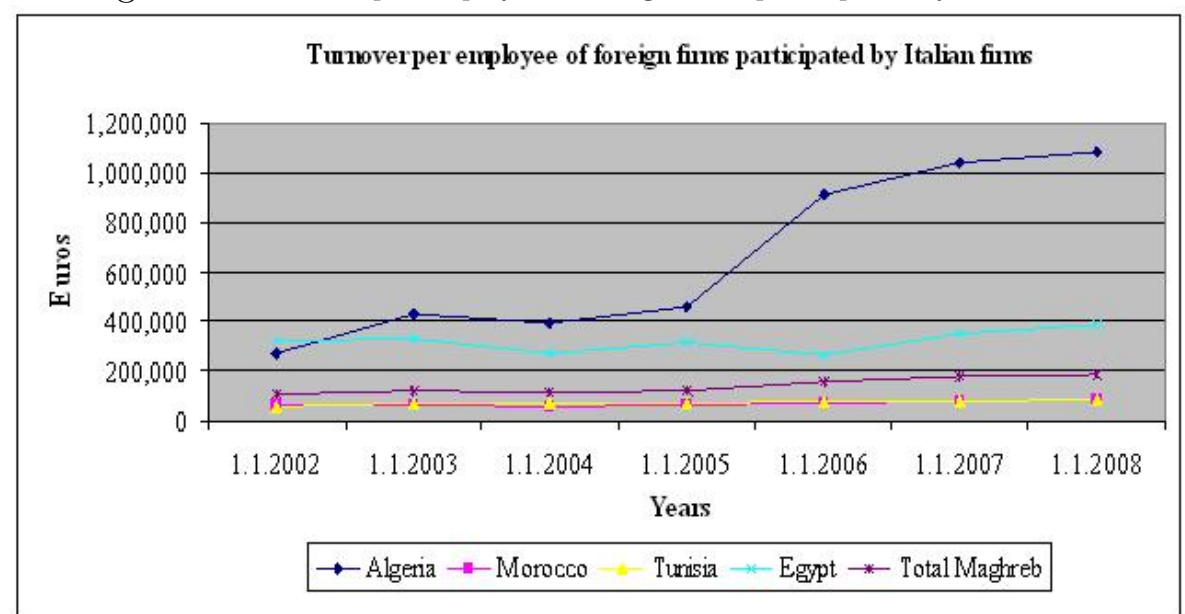

Source: our elaboration on ICE - Reprint Milan Polytechnic data 


\section{References}

[1] M. Ando, Fragmentation and Vertical Intra-Industry Trade in East Asia, North American Journal of Economics and Finance, 17 (2006), pp. 257-281.

[2] G. Gereffi, J. Humphrey, and T. Sturgeon, The Governance of Global Value Chains, Review of International Political Economy, 12 (2005), pp. 78-104.

[3] F. Kimura And M. Ando, Two-Dimensional Fragmentation in East Asia: Conceptual Framework and Empirics, International Review of Economics and Finance, 14 (2005), pp. 317-348.

[4] S. Miroudot and A. Ragoussis, Vertical Trade, Trade Costs and FDI, OECD Trade Policy Working Papers, 89 (2009). 